\title{
EFFECT OF GLAZED LOGGIAS ON THE ENERGY EFFICIENCY OF A T08B PREFABRICATED DWELLING - A CASE STUDY
}

\author{
Roman RUHIG ${ }^{*}$, Ema RUHIGOVÁ ${ }^{1}$
}

\begin{abstract}
The topic focuses on current solutions of interspaces in the renovation and modernization of residential buildings, the design of which is conditioned by the principles of sustainable development and construction. It concerns the integration of closed interspaces in renovated buildings from the 1950s to the 1980s. One example is the frequent glazing of loggias/balconies in original panel construction. The form of glazing of loggias and balconies is not regulated and is chosen by the apartment owners. For these reasons, the integration of interspaces in renovated buildings should be supported by research that will bring new insights about their effect on assessments of the energy performance of residential buildings and their effect on the architectural expression of facades. The paper compares alternatives for the integration of interspaces with an emphasis on the efferc of their orientation. The research should serve to help regulate the glazing of loggias in residential panel buildings.
\end{abstract}

\section{Address}

1 Dept. of Specific Research: Building construction and architecture, Dept. of Architecture, Faculty of Civil Engineering, Slovak University of Technology, Bratislava, Slovakia

* Corresponding author: roman.ruhig@stuba.sk

\section{Key words}

- Interspace,

- Sustainable architecture,

- Renovation,

- Residential buildings,

- Buffer zone,

- Construction panel systems.

\section{INTRODUCTION}

As populations increase, household energy consumption and waste increase as well. This fact is logically and directly proportional, and our task should be to reduce the use of primary energy and waste in buildings. One indicator discussses the number of Earth-sized planets (how many Earth-sized planets would we need to eliminate ecological and climatic problems) that a country's eco-track would require if the every country left the same eco-footprint without exceeding its biocapacity. In the case of Slovakia in 2013, it was 2.61 planet Earths ${ }^{1}$ (if all the countries in the world behaved like Slovakia in terms of ecology). The exact number depends on the measures taken. For this reason, it is necessary to look for optimal solutions that reduce energy consumption. One of the possibilities is a search for new renewable sources or a more efficient use of already-known energy sources. Improvements in the energy performance of a building could involve interspaces such as balconies, loggias, terraces, greenhouses, and conservatories with added functionality. Residential buildings from the 1950 s to the 1980 s accounted for up to $60 \%$ of the building stock in Slovakia in 2001, which means a huge expenditure of energy for their renovation ${ }^{2}$. At present, apartment owners in residential buildings arbitrarily glaze loggias/balconies, which in most cases leads to a loss of architectural quality. For this reason, the paper also deals with the integration of interspaces into the T08B structural panel system.

\footnotetext{
Source: Adrián Ondrovič, International comparison of the ecological footprint of Slovakia, Slovakia, 2017

Source: Alexandra Troi, Institute for Renewable Energy, EURAC research, Bolzano, Italy, 2001
} 


\section{SUBJECT OF THE WORK}

At present, residential buildings often have balconies, loggias, terraces, atriums and suspended structures, that can be either open or closed. In the past, interspaces were already used in the architecture, construction and energy sectors. Nowadays, the application of conservatories as an energy source is in decline due to the technical possibilities of using alternative sources. Their use in modern buildings has ceased to be a topic of interest. However, their application still occurs in the renovation of buildings. One example is the unregulated glazing of loggias/balconies in the original panel construction by apartment owners. For this reason, their integration into renovated buildings should also be supported by research that would bring new insights into their impact on the assessment of the energy performance of an apartment building and subsequently serve as a basis for regulation. Many companies deal with this issue and offer their products to customers, but without any architectural inventiveness. The unregulated realization of the glazing of interspaces completely destroys the silhouette and expression of a given building. Therefore, separating existing interspaces from the heated volume capacity and defining them as buffer zones can improve energy efficiency. At present, there is not enough research conducted on the effect of interspaces with added functions on assessment of the energy performance of renovated buildings, which can also affect the architectural expression of the facade and the layout of the housing unit. The paper compares alternatives for the integration of interspaces in a building with an emphasis on the effect of their orientation.

\section{RESEARCH METHODOLOGY}

The verification of an assessment of the energy performance of the T08B panel construction system will be undertaken. For an improved generalization and comparison, the calculations will only be performed within the limits of the existing volume of the given construction. Outbuildings, superstructures, and other suspended structures should not be based on the existing builtup area in which the original buildings were built. The exception is thermal insulation, which slightly increases the volume of the building, but does not worsen its shape factor. The advantage of this limit is also the preservation of existing structures as a part of cultural sustainability. The research compares 4 variant solutions for the integration of a loggia with different orientations into a building. Three variants will be insulated according to the recommended target values set out in the STN 73 0540-2 standard. In the first variant, the glazing of the loggia is not considered. In the second and third variants, the loggia is considered to be glazed, but is not part of the heated volume capacity. These alternatives have different types of glazing and are perceived as buffer zones. In the fourth alternative, a loggia is considered that is integrated into the heated volume capacity. A promising method that would solve the parameters of the internal environment for the energy calculations is the hour-based method (dynamic simulation). Its simulation could be of issue depending on a person's lifestyle, which would be difficult to grasp in the calculations due to excessive ventilation during the winter months or almost no ventilation. For this reason, the subject of the work at this stage is mainly focused on the simplified calculation of the computational energy of the building according to STN 73 0540-2, which is referred to in Decree 364/2012 Coll. on the energy assessment of a building. The human factor is also not taken into account in the Slovak technical standards. This calculation is intended to provide only approximate calculations for understanding the current glazing of loggias and their future regulation. The simplified calculations should then be verified by more complex simulations or measurements in the field. However, only a few alternatives have been identified that are worth further simulations. The period of the 1950s to the 1980s brought many new construction systems for panel housing construction. Based on the ratio analysis of the interspaces to the built-up area of the floor, the T 08 B structural panel system was chosen. Subsequently, the specific energy demand for heating in all the variants is calculated. These calculations will be compared and, based on the calculations, the thickness of the thermal insulation in the heat-exchange envelope of the building will be optimized. The compared alternatives will also respond to the issue of which side a building of this type is oriented towards and work with the bx reduction factor for the buffer zones. The calculation of the evaluation of the energy efficiency will be done with ISOVER Fragment 5.0 and ISOVER Project Evaluation 1.0 (PEHA).

\section{INFLUENCE OF WINTER GARDENS (LOGGIES) ON THE ENERGY DEMANDS FOR HEATING PER SEASON ACCORDING TO THEIR ORIENTATION}

\subsection{Introduction to the issue of T 08 B apartment buildings}

A specific feature of a T 08 B residential panel house is the dominance of loggias on one of the facades (the share of loggias in the built-up area of a floor is $9.47 \%$ ). "The medium-span construction system T 08 B enabled the construction of terraced houses with 4 and 8 floors and stand-alone houses with 11 residential floors. The modular outline of the load-bearing walls is $6,000 \mathrm{~mm}$. The construction height is $2,800 \mathrm{~mm}$ (Fig. 1). The construction system in question was built in Czechoslovakia in the 1970s and 1980s with 8 to 12 floors with two or more sections" (Sternova, 2006). In the case study presented, a panel house with 9 floors and two sections, which was often built on the territory of the Slovak Republic is discussed. There are a total of 48 apartments in the residential building. The loggias are located only on the south side and are directly connected to the living room and kitchen.

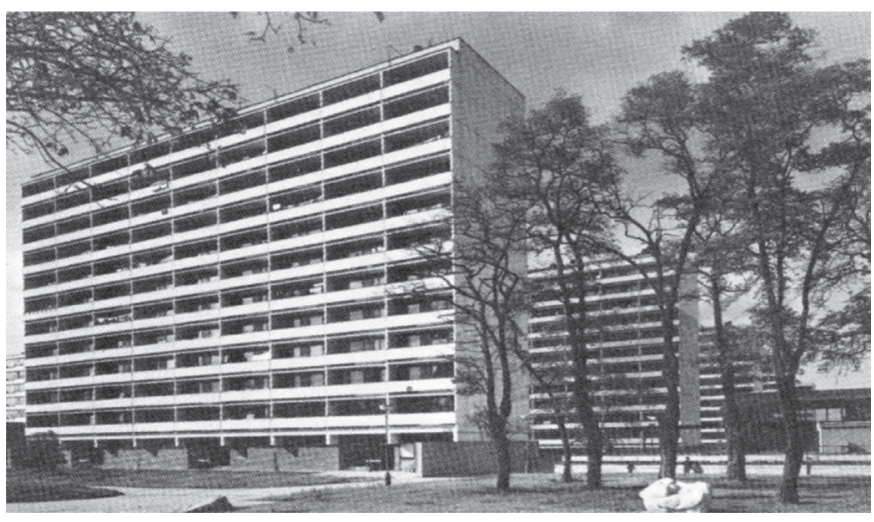

Fig. 1 T 08 B construction system (12-storey house with three sections), Prague - Pankrác 1 (Source: www.estav.cz, 2020) 


\subsection{Location and boundary conditions}

The boundary conditions were taken from the STN 73 0540-3 thermal technical standard. The case study was conducted in the city of Bratislava, which, according to the standard, is located in the temperature area 1 with an altitude of 140 and wind area of 2. The external calculation temperature was considered for the city of Bratislava with a value of $-11^{\circ} \mathrm{C}$ (calculation area $-10^{\circ} \mathrm{C}$ ) with a design relative humidity of the outdoor air of $83.2 \%$. The proposed indoor temperature used for the apartment buildings (dwellings) was $20^{\circ} \mathrm{C}$ with a design relative humidity of $50 \%$.

\subsection{Analysis of the principles for assessing the need for energy for heating according to Slovak technical standard STN 73 0540-2 and the procedure for calculating the specific energy for heating}

Variant solutions in the present case study were calculated by a simpler method for the purpose of verifying the established hypotheses; variants for more detailed additional research would then be selected. The simplified calculation method used in the work took into account the thermal technical requirements of the standard, such as the heat, humidity and air propagation through the building structure, the specific heat demands, and energy performance of the building as well as the thermal stability of the room. The technical standard from which the procedure for calculating the specific energy demands for heating was taken is the standard STN 73 054540-2, part 2: Functional requirements. "This standard applies to the design and assessment of building structures and buildings with the required temperature of the indoor environment when used. It sets out the thermal technical requirements for building structures and buildings, which ensure the fulfillment of basic requirements for buildings, in particular the fulfillment of the basic requirement for energy efficiency and heat retention and the provision of hygiene, health and environmental protection" (STN 73 04540-2, 2019). The standard deals with the required thermal technical properties of building structures and buildings, which were also taken into account in the research calculations in question. According to the given standard, the following quantities are assessed: "a) the heat transfer coefficient of the structure (thermal resistance of the building structure), b) the internal surface temperature of the building structure, c) the amount of the condensed and evaporated water vapor in the building structure per year, d) the air permeability of the joints of building structures, e) the thermal acceptance of the floor structure, f) the heat demands for heating, g) the thermal stability of the room" (STN 73 04540-2, 2019).

The procedure for calculating the specific energy demands for heating in the given case study werw:

1. Calculation of the heat transfer coefficient $U\left[\mathrm{~W} /\left(\mathrm{m}^{2} . \mathrm{K}\right)\right]$ and thermal resistance of the structure $R\left[\mathrm{~m}^{2} . \mathrm{K} / \mathrm{W}\right]$

2. Calculation of the areas of the individual fragments and basic dimensions of the structure

3. Calculation of the specific heat loss by heat transfer $H_{T}$ $[\mathrm{W} / \mathrm{K}]$

4. Taking into account the effect of thermal bridges $H_{v}[\mathrm{~W} / \mathrm{K}]$

5. Calculation of the specific heat loss $H[\mathrm{~W} / \mathrm{K}], \mathrm{H}=\mathrm{H}_{\mathrm{T}}+$ $\mathrm{H}_{\mathrm{v}}[\mathrm{W} / \mathrm{K}]$

6. Calculation of the solar gains $Q_{s}[\mathrm{kWh}]$

7. Calculation of the internal gains $Q_{i}[\mathrm{kWh}]$
8. Calculation of the total internal gains $Q_{i s}[\mathrm{kWh}]$, $\mathrm{Q}_{\mathrm{is}}=\mathrm{Q}_{\mathrm{i}}+\mathrm{Q}_{\mathrm{s}}[\mathrm{kWh}]$

9. Calculation of the heat for heating $Q_{h}[\mathrm{kWh} / \mathrm{a}]$, $\mathrm{Q}_{\mathrm{h}}=82,1\left(\mathrm{H}_{\mathrm{T}}+\mathrm{H}_{\mathrm{v}}\right)-0.95 \cdot\left(\mathrm{Q}_{\mathrm{i}}+\mathrm{Q}_{\mathrm{s}}\right)[\mathrm{kWh} / \mathrm{a}]$

10. Calculation of the need for energy for heating $Q_{\text {he }}$ $[\mathrm{kWh} / \mathrm{a}], \mathrm{Q}_{\mathrm{he}}=\left(\mathrm{Q}_{\mathrm{h} .}\left(100+\mathrm{s}_{\mathrm{oh}}+\mathrm{sr}_{\mathrm{h}}\right)\right) / \eta \mathrm{h}[\mathrm{kWh} / \mathrm{a}]$

- heat production efficiency: $\eta_{h}=75 \%$

- heat transfer loss: $s_{o h}=8.5 \%$

- loss on heat distribution: $s_{r h}=6 \%$

11. Calculation of the specific energy demands for heating $q_{h e}$ $\left[\mathrm{kWh} /\left(\mathrm{m}^{2} . \mathrm{a}\right)\right], \mathrm{qhe}=\mathrm{Q}_{\mathrm{he}} / \mathrm{A}_{\mathrm{b}}$

\subsection{Type of construction and material solutions}

The selected fragments of the heat-exchange envelope are the same in all the variant solutions of the integration of the loggia due to the generalization of the results. The existing perimeter cladding with a thickness of $240 \mathrm{~mm}$ is non-load bearing and consists of aerated concrete panels. The gable walls consist of two layers with $190 \mathrm{~mm}$-thick internal reinforced concrete load-bearing walls and $240 \mathrm{~mm}$-thick external cladding aerated concrete panels. The gable wall is $440 \mathrm{~mm}$-thick. The roof cladding was designed as a single-skin ventilated flat roof structure. The vertical load-bearing walls are made of $190 \mathrm{~mm}$-thick reinforced concrete panels. The ceiling structures are made of $190 \mathrm{~mm}$-thick prestressed hollow reinforced concrete panels. The perimeter walls are designed with $200 \mathrm{~mm}$-thick mineral wool insulation. The flat roof is designed with $400 \mathrm{~mm}$-thick stone (basalt) wool insulation. The interior ceiling with the heat flow from the top to the bottom (between the first and second floors) is designed with $400 \mathrm{~mm}$-thick extruded polystyrene insulation. The thermal resistance of the structures was assessed according to the thermal technical standard STN 73 0540-2 to the target recommended value, which is valid as of 2021. The structures were calculated with the ISOVER Fragment 5.0 program. The individual fragments of the $\mathrm{T} 08 \mathrm{~B}$ construction system are calculated in the ISOVER Fragment 5.0 program.

\subsection{Variant solutions for the interspace}

In the present case study, four variants for access to the loggias were considered. The first variant accepts the original state, where the railings are left in the loggias, and no glazing is added. In the second and third variants, the loggias are glazed, thereby creating a buffer. According to the thermal technical standard STN 73 05402 , the glazing in these spaces can be either single, double or with thermal insulating double glazing $U_{g} \leq 2.0 \mathrm{~W} /(\mathrm{m} 2 . \mathrm{K})$. In the second alternative, we considered single glass and the reduction factor $b_{x}=0.7$. In the third alternative, we considered double glazing $U_{g} \leq$ $2.0 \mathrm{~W} /(\mathrm{m} 2 . \mathrm{K})$, where the bx reduction factor (that depends on the dividing structure) is $b_{x}=0.50$, which results in a reduction of heat losses (HT) through the heat-exchange envelope of the building. In the fourth variant, the loggias are integrated into the heated volume of the building.

\subsection{Calculation parameters input}

The energy evaluation calculations will work with the standardized input data taken from the STN 73 0540-2 and STN 73 
0540-3 standards, which should generalize the results and could be directly applied in practice. The calculation parameters input are the same in all the variants, except for the dimensions of the structure, which depend on the heated volume capacity of the given variant. The input data can be used by researchers for an analysis by other methods.

The calculation parameters input used for all the variants where:

1. Heat transfer coefficient $U\left[\mathrm{~W} /\left(\mathrm{m}^{2} . \mathrm{K}\right)\right]$ and the $R$ thermal resistance of the structure $\left[\mathrm{m}^{2} . \mathrm{K} / \mathrm{W}\right]$ heat-exchange envelope. The material solution and composition of the fragments are described in sections 4.4 and 4.5.

- Perimeter wall 1: $\left.U=0.143 \mathrm{~W} /\left(\mathrm{m}^{2} . \mathrm{K}\right)\right]$, $R=6.817 \mathrm{~m}^{2} . \mathrm{K} / \mathrm{W}$

- Perimeter wall 2: $U=0.140 \mathrm{~W} /(\mathrm{m} 2 . \mathrm{K})]$, $R=6.95 \mathrm{~m}^{2} . \mathrm{K} / \mathrm{W}$

- Flat roof: $U=0.093 \mathrm{~W} /(\mathrm{m} 2 . \mathrm{K}), R=10.619 \mathrm{~m}^{2} . \mathrm{K} / \mathrm{W}$

- Ceiling over unheated space: $U=0.295 \mathrm{~W} /\left(\mathrm{m}^{2} . \mathrm{K}\right)$, $R=3.045 \mathrm{~m}^{2} . \mathrm{K} / \mathrm{W}$

- Windows, glass doors: $U=0.84 \mathrm{~W} /\left(\mathrm{m}^{2} . \mathrm{K}\right)$

2. Information about the building: residential dwelling, reconstruction

3. Taking into account the effect of any thermal bridges (insulated structures): $\Delta U=0.05 \mathrm{~W} /\left(\mathrm{m}^{2} . \mathrm{K}\right)$

4. Air exchange intensity (normative value from the hygienic criterion): $n=0.51 / \mathrm{h}$

5. Normalized number of degree-days $\mathrm{D}=3.422 \mathrm{~K}$.day and from the comparative difference of the indoor air temperature of $20^{\circ} \mathrm{C}$ and the average outdoor air temperature in the winter period of $3.86^{\circ} \mathrm{C}$ and 212 heating days for buildings with uninterrupted heating

6. Total energy of solar radiation $I_{s j}\left[\mathrm{kWh} /\left(\mathrm{m}^{2}\right)\right]$ per unit area with orientation $j$ during the standard heating season: north $=100$, south $=320$, east and west $=200$, southwest and southeast $=260$, northeast and northwest $=130$, horizontal orientation $=240$

7. Solar factor of glass $g$, which determines how much energy from sunlight penetrates into the interior in the form of heat: $g=0.6$

8. Average heat output of the internal heat source, depending on the function of the building: $q_{I} \leq 5$ (residential building)

Depending on the dividing structure, the reduction factor $b x$ has a significant effect on the overall calculations. This factor is used to calculate the specific heat loss $H_{T}$ and is considered in- stead of the difference in temperature between an indoor heated environment and an outdoor environment or adjacent space.

- through an outer wall, window, outer door, flat roof: $b_{x}=1.0$

- through a ceiling of an unheated area (1st floor): $b_{x}=0.5$

- through an wall and an opening into an unheated glazed space, which has single glazing: $b_{x}=0.7$, and which has glazing with thermal insulation double glazing $U_{g} \leq 2.0 \mathrm{~W} /\left(\mathrm{m}^{2} . \mathrm{K}\right)$.

The calculation parameters input for the individual variants are shown in Table 1.

\subsection{Parameters not considered in the calculations}

The paper in question is only an expert estimate based on simplified standard procedures that have been adapted to the problem. Due to its generalization, the following parameters were not considered:

1. The mutual shading of buildings.

2. The effect of shielding the loggia.

3. Shading by exterior or interior elements in the heating period.

4. The solar factor $g$ was only considered for the glazing proposed in the heat-exchange envelope.

5. In the summer the interior will not overheat due to the glazing of the loggias, as the maximum opening of these structures is considered.

6. The contribution only considers a comprehensive renewal of the housing stock, where forced ventilation (recuperation units) will be implemented, and natural ventilation through the loggias will be secondary.

7. The human factor, which is also not considered in the standard.

8. Different cloud patterns and changes in the atmosphere during the day.

\subsection{Impact on the architecture of the building}

ňThe architectural solution of the given case study lies mainly in the work with the expression of the loggia and the related changes in disposition. The rear of the apartment building (on the northern side by the staircase) is significantly monotonous in a single grid (Fig. 2). The disturbed monotony takes place only in the base, where there are entrances to the individual sections.

Tab. 1 Comparison of the energy demands for heating per season of a building after it is insulated in all the selected orientations (Source: Ruhig, 2021)

\begin{tabular}{|l|c|c|c|c|}
\hline $\begin{array}{l}\text { Variant solutions for integrating a loggia into } \\
\text { a building }\end{array}$ & $\begin{array}{l}\text { Heated volume: } \\
\boldsymbol{V}_{\boldsymbol{b}}\left(\mathbf{m}^{\mathbf{3}}\right)\end{array}$ & $\begin{array}{l}\text { Specific heated area: } \\
\boldsymbol{A}_{\boldsymbol{b}}\left(\mathbf{m}^{2}\right)\end{array}$ & $\begin{array}{l}\text { Area of windows and } \\
\text { glass doors: } \\
\boldsymbol{A}\left(\mathbf{m}^{2}\right)\end{array}$ & $\begin{array}{l}\text { Factor } \boldsymbol{b} \boldsymbol{x} \text { at } \\
\text { wall loggia }\end{array}$ \\
\hline 1. Without loggia glazing & $11,294.724$ & 3828.72 & 660.96 & $\mathbf{1 . 0}$ \\
\hline $\begin{array}{l}\text { 2. Glazed loggia as a buffer space, loggia glazing } \\
\text { with single glass }\end{array}$ & $11,294.724$ & 3828.72 & $\mathbf{0 . 5}$ \\
\hline $\begin{array}{l}\text { 3. Glazed loggia as a buffer space, loggia glazing } \\
\text { with double glazing } U g \leq 2.0 \mathrm{~W} /\left(\mathrm{m}^{2} . \mathrm{K}\right)\end{array}$ & $11,294.724$ & 3828.72 & 660.96 & $\mathbf{0 . 7}$ \\
\hline 4. Glazed loggia within the heated volume capacity & $12,345.396$ & 4184.88 & 720 & $\mathbf{1 . 0}$ \\
\hline
\end{tabular}




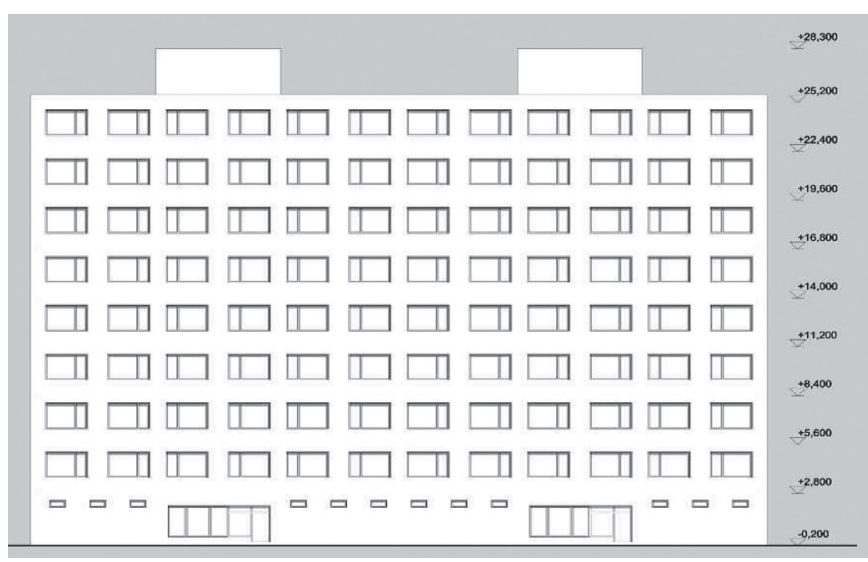

Fig. 2 Variant 1 - Rear view of the T08 B apartment building existing condition (Source: Ruhig, 2020)

On the front, the grid is also preserved over the entire area. The tectonics of the area are disturbed by the loggias, which are perceived as added to the total volume, thanks to which the overall expression is dematerialized. The loggias form a certain zone between the exterior and the interior, which creates an optical filter between these spaces (Fig. 3).

The solution to the loggias in the design itself is largely influenced by the energy concept. The design with buffer zones allows the loggia to be glazed to its full height (Fig. 4). In this case, the loggia is not within the heated volume capacity and does not form part of the fire compartment. For this reason, fire strips between the windows are considered to be outside the loggia's glazing. The original tectonics of the facade are slightly disturbed. When the conservatories are closed in the winter months, the loggias lose depth, and the original plasticity of the building is suppressed. In the summer months, however, the upper part of the glazing can be opened $100 \%$, thanks to the rail sliding system. The design with conservatories respects the original tectonics of the facade, thanks to the solid masonry (insulated) part of the conservatory, which cites the original railing (Fig. 5). By adding the loggia to the heated volume capacity, the loggia becomes part of the fire compartment. For this reason, the masonry strips are also justified in terms of fire safety, where there must be a distance of at least $900 \mathrm{~mm}$ between the windows. The other part is glazed, and there is a similar adverse effect as in the variant with a bumper zone. In the winter months, the glazing is mostly closed and the facade

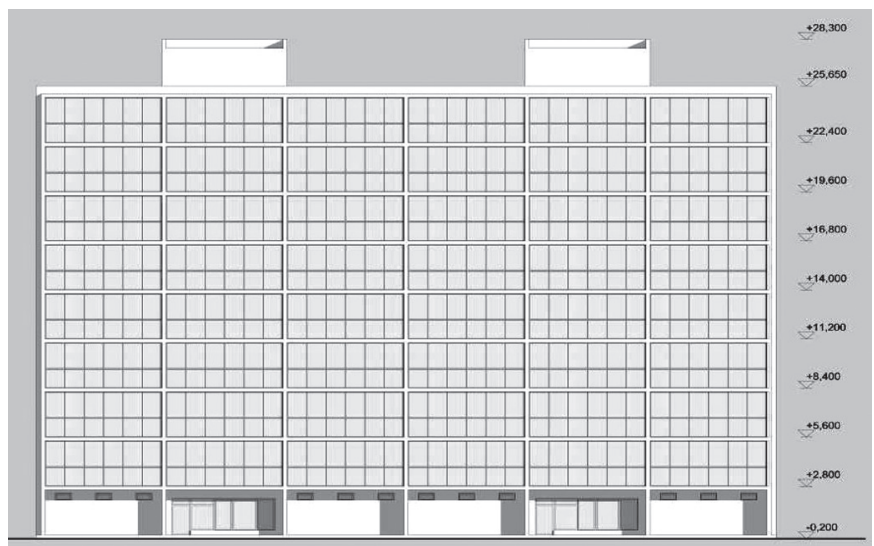

Fig. 4 Variant 2,3 - Front view of the T 08 B apartment building - design with buffer zones in the position of the loggias (Source: Ruhig, 2020)

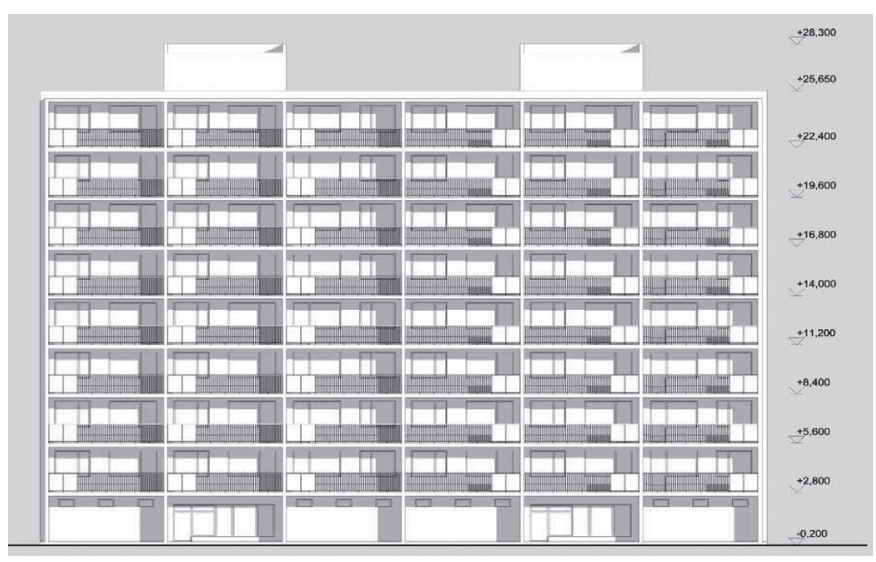

Fig. 3 Variant 1 - Front view of the T 08 B apartment building existing condition (Source: Ruhig, 2020)

loses its plasticity. In the summer months, it is possible to open the glass part, but it is questionable as to what extent, because in this variant, the glazing of the loggia is part of the heat-exchange envelope.

\subsection{Energy concept}

The fourth variant was solved in the calculations: (1). without any loggia glazing (Fig. 6); (2). the glazed loggia as a buffer space, loggia glazing with a single glass (Fig. 7); (3). the glazed loggia as a buffer space, the loggia glazing with double glazing $U_{g} \leq 2.0 \mathrm{~W} /\left(\mathrm{m}^{2} . \mathrm{K}\right)$ (Fig. 7) and (4). the glazed loggia within the heated volume capacity (Fig. 8). All the variants were assessed with and without insulation. The design of the new heat-exchange envelope was solved with the insulation. Only the railing and part of the perimeter masonry at the loggias, which is infill and has no load-bearing function, have been removed. The above-ground floor, in which the communication and technical spaces are located, was not considered to be heated. One of the effects on the assessment of the energy performance of the building was also its location on the land and its orientation to the cardinal points. Because the same type of prefabricated apartment building does not have to be oriented to only one side, it was necessary to choose the main representatives where the same calculations would take place. The northern, northeastern and northwestern sides were not

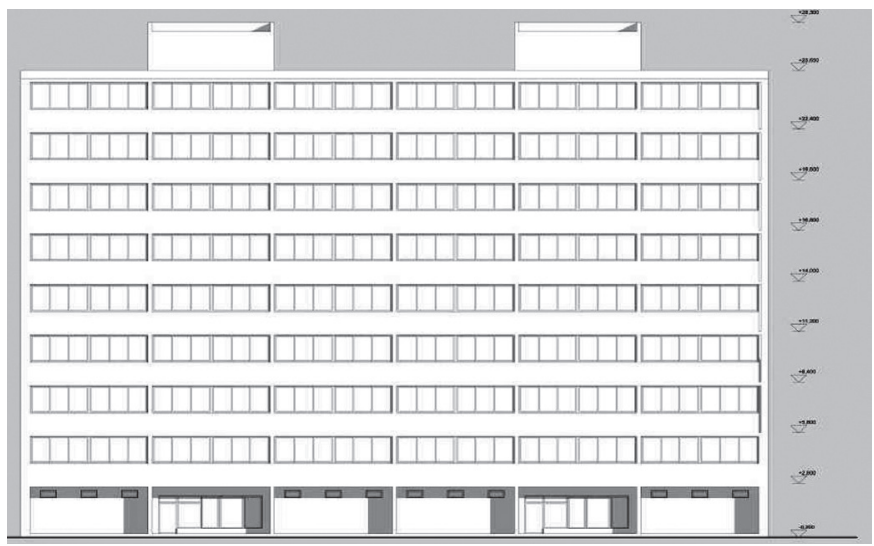

Fig. 5 Variant 4 - Front view of the T 08 B apartment building - interconnection of the loggia into the heated volume capacity (Source: Ruhig, 2020) 


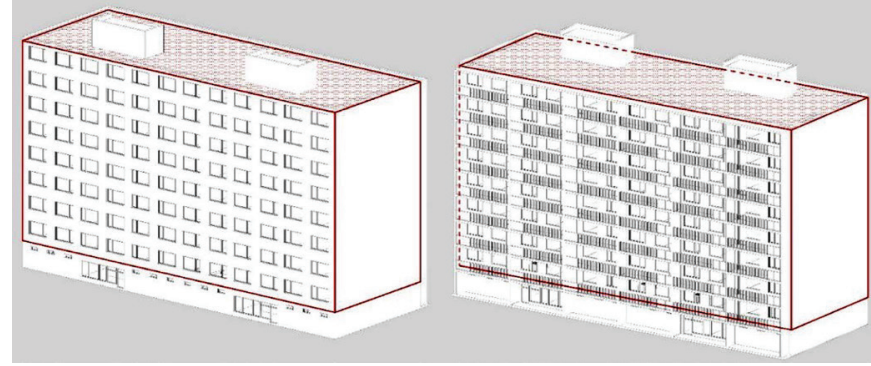

Fig. 6 Variant 1 - Boundary of the heated volume capacity in an axonometric view - state without loggia glazing (the red defines the heated volume capacity) (Source: Ruhig, 2020)

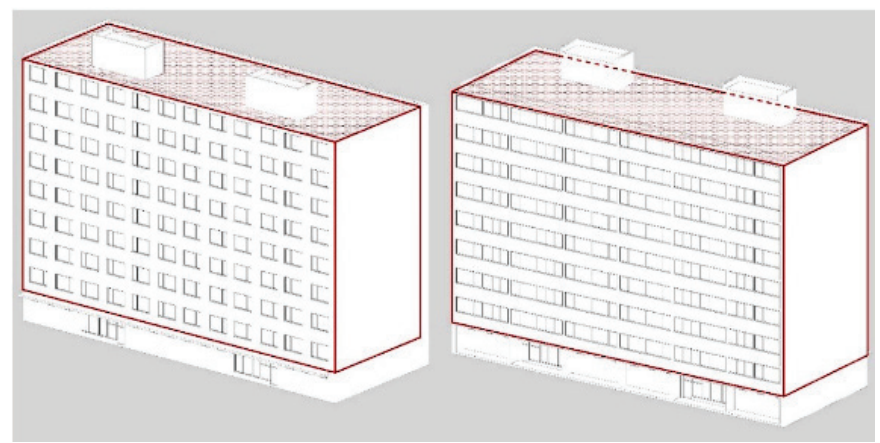

Fig. 8 Variant 4 - Boundary of the heated volume capacity in an axonometric view - glazed loggia within the heated volume capacity (the red defines the heated volume) (Source: Ruhig, 2020)

taken into account, as buildings of this type have never been oriented towards these sides. The heat gains from solar radiation on the southwest and southeast side are the same as those on the east and west sides. There are no windows on the side facades. Only the front facades were important, for which the three cardinal points were finally chosen, i.e.) the southwest, south, and west.

\subsection{Final evaluation of the case study}

In the case study presented, the energy efficiency of the renovation of a T 08 B system apartment building, the layout of the apartment unit, the architectural solution of the loggia glazing, and the impact of the energy-efficient interspace on the overall

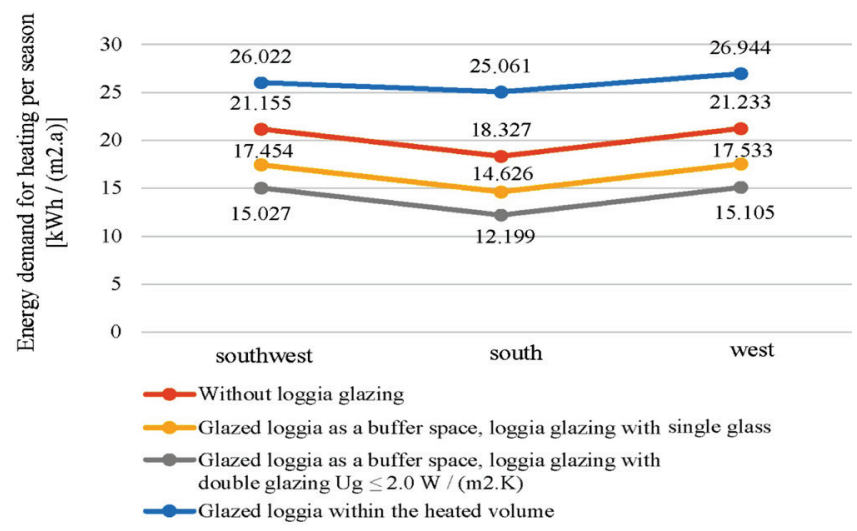

Fig. 9 Graph of energy demands for heating per season, depending on which side a building of this type is oriented towards (Source: Ruhig, 2021)

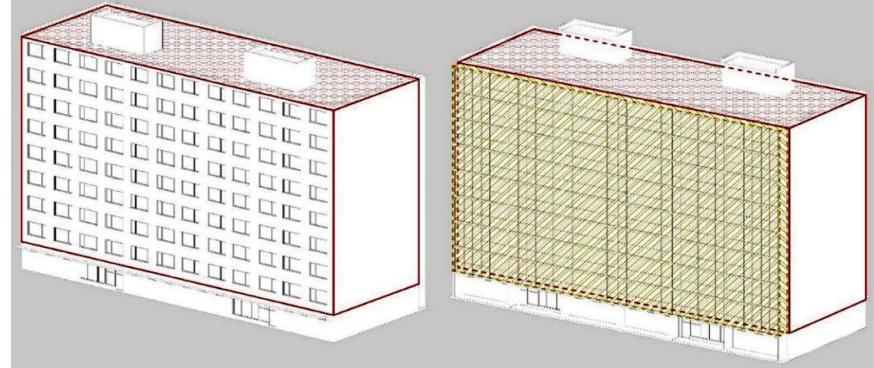

Fig. 7 Variants 2,3 - Boundary of the heated volume capacity in an axonometric view - glazed loggias as a buffer zone (the red defines the heated volume; the yellow defines the buffer zones) (Source: Ruhig, 2020)

energy efficiency of the building were addressed. The research was undertaken as a basis for the selection of the type of interspace, the result of which depended on the degree of use of thermal insulation, the degree of the integration of the loggia into the heated volume capacity, and the orientation of the building. It is clear from Figure 9 that the orientation has a significant impact on the energy efficiency of the building in this construction system and that the results are different, depending on which side a building of this type is oriented towards. The variant works best with the use of conservatories with the heated volume capacity oriented towards the south, thanks to which the energy efficiency has improved by $35.53 \%\left(11.816\left(\mathrm{kWh} /\left(\mathrm{m}^{2} . \mathrm{a}\right)\right)\right.$. This is the most radical improvement over the 8 other combinations. This variant should therefore be used in the application of optimizing the thermal insulation.

\subsection{Optimization of the heat-exchange building envelope}

In the final comparison of the individual alternatives, the most favorable variant was based on the idea that the loggia was considered as a buffer zone, which was also oriented towards the south. The specific energy demand for heating in this variant is $12.199 \mathrm{kWh} /\left(\mathrm{m}^{2} . \mathrm{a}\right)$. If we compare this variant to the variant which is also insulated and oriented towards the south but with an unglazed loggia, we get a specific energy demand for heating of $18.327 \mathrm{kWh} /\left(\mathrm{m}^{2} . \mathrm{a}\right)$, which is $33.43 \%$ worse than for the variant with a buffer zone. The first variant is insulated without glazing the loggias. The heat-exchange envelope complies with the standard STN 73 0540-2 to the recommended target value (Fig. 10). The integrated loggia in the heated volume capacity (variant 4) has more negative resulting values of the specific energy for heating than variant 1 , which does not consider glazing the loggias. Therefore, we do not consider this alternative when optimizing the thermal insulation.

In the second variant, there is a loggia acting as a buffer space with the loggia glazed with simple glass and using insulations that meet the standard STN 73 0540-2 to the recommended target value. Thanks to the glazing of the loggias and the use of the reduction factor $b_{x}=0.7$, we can reduce the demands on the transparent structures and instead use windows with triple glazing and the heat transfer coefficient $U_{w}=0.84 \mathrm{~W} /\left(\mathrm{m}^{2} . \mathrm{K}\right)$, or double glazing (or triple glazing) with the heat transfer coefficient $U_{w}=1.05 \mathrm{~W} /\left(\mathrm{m}^{2} . \mathrm{K}\right)$. In this case, the transparent structures do not meet the recommended target values according to the STN 73 0540-2 standard (Fig. 11), 


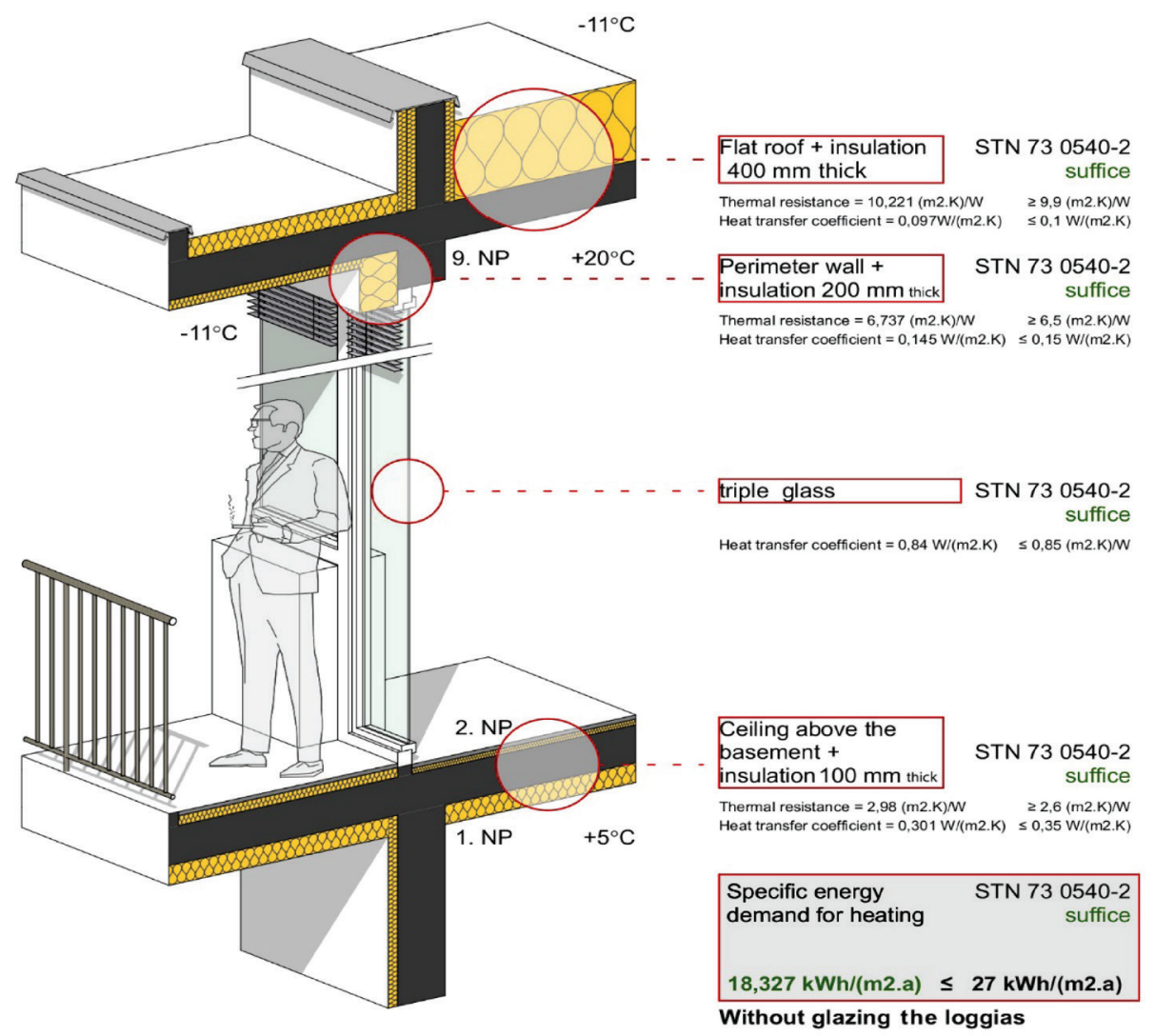

Fig. 10 Optimization of the thermal insulation shown in 3D detail - without glazing the loggias (Source: Ruhig, 2020)

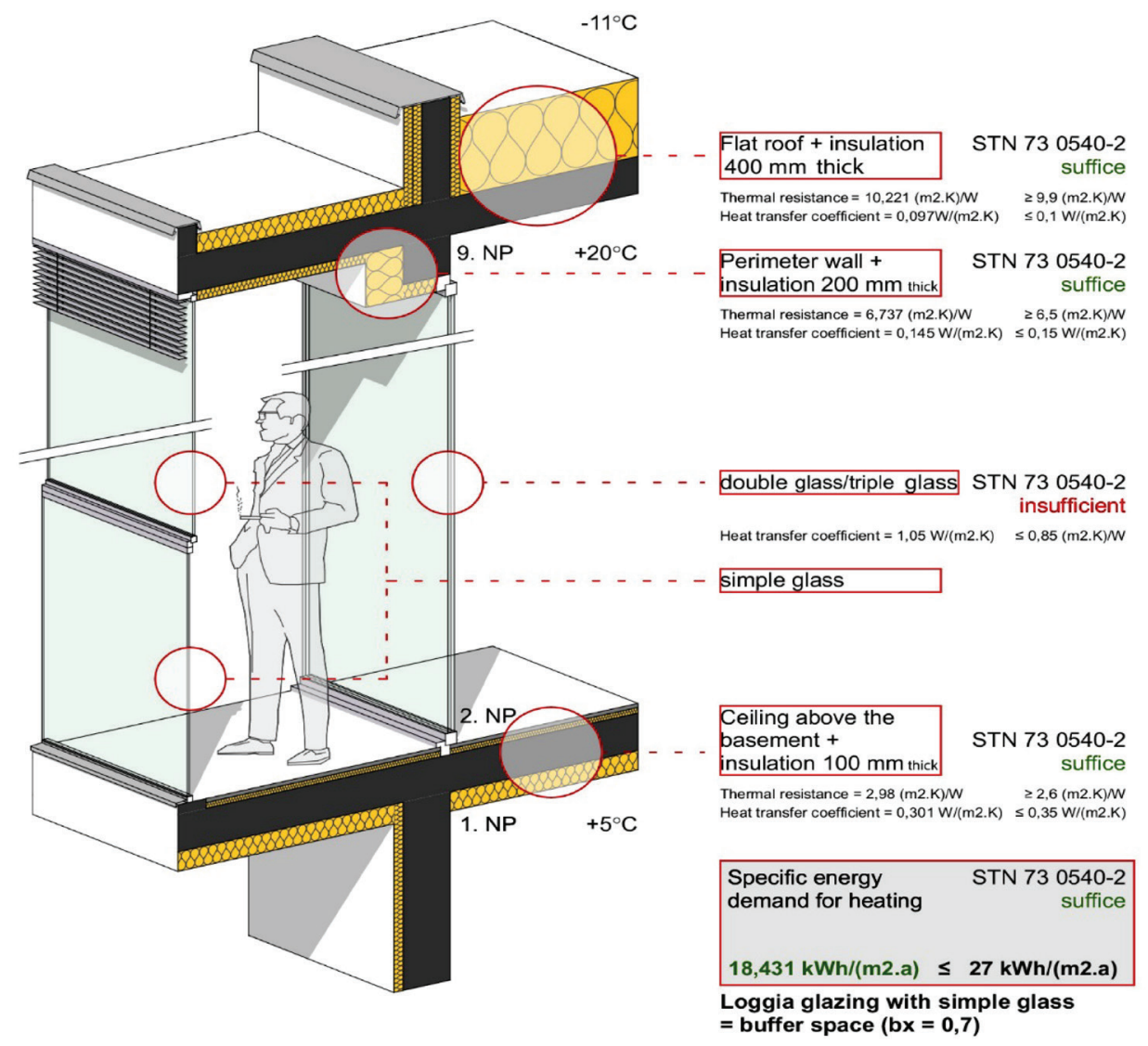

Fig. 11 Optimization of the thermal insulation shown in $3 D$ detail - glazing the loggia with a single glass $=$ buffer space $\left(b_{x}=0.7\right)$ (Source: Ruhig, 2020) 


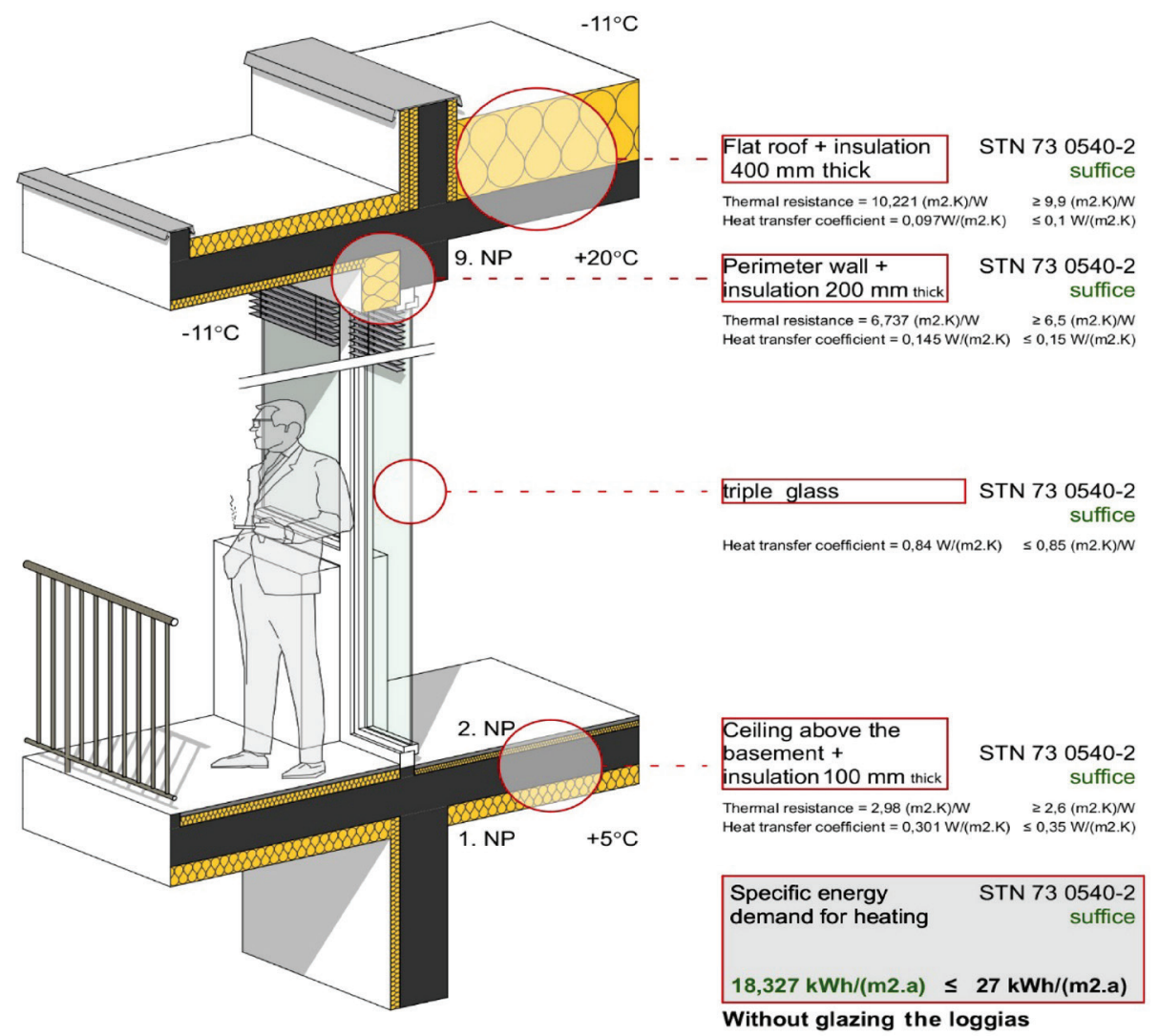

Fig. 12 Optimization of the thermal insulation shown in $3 D$ detail - glazing the loggia with double glazing $U_{g} \leq 2.0 \mathrm{~W} /\left(\mathrm{m}^{2} . \mathrm{K}\right)=$ buffer space $\left(b_{x}=0.5\right)$ (Source: Ruhig, 2020)

but the specific energy demands for heating are almost identical to the previous variant.

The third variant considers a loggia as a buffer space with double-glazing where $U_{g} \leq 2.0 \mathrm{~W} /\left(\mathrm{m}^{2} . \mathrm{K}\right)$. Thanks to glazing the loggias and using the reduction factor $b_{x}=0.5$, we can reduce the demands on the transparent structures and, instead of windows with triple glazing and the heat transfer coefficient $U_{w}=0.84$, use double glazing with the heat transfer coefficient $U_{w}=1.20$. At the same time, we can reduce the thickness of the thermal insulation on the perimeter wall from $200 \mathrm{~mm}$ to $180 \mathrm{~mm}$. The transparent structures and thermal insulation in this case do not meet the recommended target values of STN 73 0540-2 (Fig. 12).

It is clear from the results that thanks to the glazing of the loggias, we can reduce the requirements for thermal insulation and transparent structures to the same final energy efficiency values of the building as in the state without the glazing of the loggias. However, it should be noted that, in this case, the structures and fragments do not meet the recommended target values according to the STN 73 0540-2 standard. The research thus proves the real impact by glazing loggias on the energy efficiency of buildings, but at the same time it points out the shortcomings in the STN 73 0540-2 thermal technical standard, which underestimates the impact of glazing a loggia on the assessment of the energy performance. The given technical standards do not take into account changes of the reduction factor $b_{x}$, depending on which side a building of this type is oriented towards.

However, it is good to mention the possible additional benefits, which are not only in the field of energy efficiency. From the point of view of the building acoustics, the buffer zones should improve the acoustic requirements in the positions of the periph- eral structures. The added transparent construction (when closed) should effectively reflect sounds coming from the exterior. As far as fire protection is concerned, the added glazing in the buffer zone could prevent the spreading of any fire. That depends on the fire resistance of the given transparent construction. Due to the possible closing of the loggia, faults in the contact between the board and the perimeter wall, which are common due to direct rain, can be prevented. However, it is necessary for the tread layers to slope into vertical rain gutters that will be located between the perimeter wall and the added glazing on the loggia.

\section{CONCLUSION}

The research has provided theoretical knowledge that has proved the real impact of glazing loggias / balconies on evaluations of a building's energy performance. At the same time, it has been shown that the position of a closed intermediate space concerning the heated volume capacity can have a significant impact on specific energy demands for heating. In the most radical alternative, the improvement in energy efficiency compared to the state without glazing the loggias was up to $33.43 \%$, which resulted in the possibility of reducing the heat-exchange envelope requirements from the recommended target values to lower required values. Therefore, one of the research recommendations is to introduce into the standard STN 73 0540-2 the possibility of taking into account glazing loggias in the calculation of energy efficiency, where fragments and transparent structures would not have to meet the recommended target values. However, the standard does not address this issue in depth. The 
standard only considers the reduction factor $b x$, which it uses according to the type of dividing structure (the reduction factor is described in section 4.6). Another benefit of the research is the knowledge that leads to a significant difference in a building's orientation and uses the same reduction factors that affect the specific energy demands for heating $b x$. The main practical benefit of the research is the basis for the renovation regulations of the facades of the T $08 \mathrm{~B}$ structural panel house with an emphasis on the glazing of loggias and their architectural design. The research was undertaken in the form of a methodology and is to serve architects and designers as a manual in optimizing the design of closed interspaces in renovating panel constructions of the construction system in question. One of the recommendations for the continuation of the topic is finding a solution to the parameters of the internal environment. To calculate the energy demands of these parameters, the method is hourly-based (dynamic simulation). However, it is necessary to partially take into account or completely omit the human factor, which could be difficult to incorporate into the calculations. 


\section{REFERENCES}

Chmúrny, I. (2003). Thermal protection of buildings. Bratislava: Jaga group, 2003, ISBN 80-88905-27-3 [in Slovak].

Janečková, M. (2018). Structural systems of prefabricated houses, development, types and floor plans. Available at: https://www. estav.cz/cz/5773.konstrukcni-soustavy-panelovych-domu-jejich-vyvoj-a-typy-pudorysy, (accessed at 30/11/2020) [in Czech]

Pifko, H. et al. (2013). The handle of sustainable architecture. Bratislava: Archinfo, 2013, ISBN 978-80-971205-1-1 [in Slovak].

Ondrovič, A. (2017). International comparison of the ecological footprint of Slovakia. In: Proceedings of the 7th International Conference Global existing risks, Žilina: STRIX ez SSŽP, pp. 108-119, ISBN 978-80-897532-16-1 [in Slovak].

Ruhig, R. (2020). Contribution to the integration of interspaces in the renewal of the housing stock from the 1950s - 80s. Bratislava, Dissertation work, SVF-13421-7452 [in Slovak]

Sternova, Z. et al. (2006). Atlas of thermal bridges. Bratislava: Jaga group, s.r.o., 2006. ISBN 80-8076-034-9 [in Slovak].

Troi, A. (2001). Historic buildings and city centres - the potential impact of conservation compatible energy refurbishment on climate protection and living conditions. Available at: https://www. eurac.edu/en/institutes-centers/institute-for-renewable-energy, (accessed at 30/11/2020).
Slovak technical standard, STN 73 0540-2:2019. Thermal protection of buildings. Thermal technical properties of building structures and buildings. Part 2: Functional requirements.

Slovak technical standard, STN 73 0540-3:2012. Thermal protection of buildings. Thermal technical properties of building structures and buildings. Part 3: Properties of the environment and construction products.

Act No. 555/2005 Coll. Act on Energy Efficiency of Buildings and on Amendments to Certain Acts.

Computer program. ISOVER Project Evaluation 1.0 [online]. https://fragment.isover.sk/apps/v5_202104141331/html/projektove hodnotenie.xhtml, (accessed at 30/11/2020).

Computer program. ISOVER Fragment 5.0 [online]. https://fragment.isover.sk/apps/v5 202104141331/html/fragment5.xhtml, (accessed at 30/11/2020). 